\title{
Statyba
}

\section{APPLICATION OF MULTICRITERIA DECISION METHODS IN RESTORATION OF BUILDINGS IN THE OLD TOWN}

\section{Ustinovičius \& S. Jakučionis}

To cite this article: L. Ustinovičius \& S. Jakučionis (2000) APPLICATION OF MULTICRITERIA DECISION METHODS IN RESTORATION OF BUILDINGS IN THE OLD TOWN, Statyba, 6:4, 227-236, DOI: $10.1080 / 13921525.2000 .10531594$

To link to this article: https://doi.org/10.1080/13921525.2000.10531594

Published online: 26 Jul 2012.

Submit your article to this journal \ulcorner

Џ Article views: 126

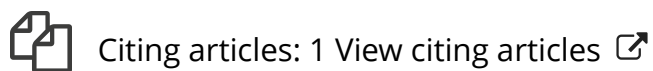




\title{
DAUGIAKRITERINIU METODU TAIKYMAS VERTINANT SENAMIESČIO PASTATU RENOVACIJOS INVESTICINIUS PROJEKTUS
}

\author{
L. Ustinovičius, S. Jakučionis \\ Vilniaus Gedimino technikos universitetas
}

\section{Ivadas}

Šiandien Lietuvoje didžioji senamiesčių pastatų dalis vis dar apleista ir laukia atgaivinimo. Sparti senamiesčiu regeneracija yra svarbi šalies ekonomikai ir kultūrai, ji tampa vis svarbesne statybos sudètine dalimi.

$1998 \mathrm{~m}$. "Socialinès informacijos centro" atlikta gyventoju apklausa parodè, kad Vilniaus miesto visuomenè svarbiausiomis senamiesčio problemomis laiko:

1) apleistus ir griūvančius senamiesčio pastatus (67\%),

2) biurokratinę projektų derinimo tvarką (17\%),

3) nepakankamą paminklų apsaugą $(9 \%)$.

Apklausos duomenys rodo, kad visuomenès požiūriu Vilniaus senamiesčio atgaivinimas yra pirmo svarbumo uždavinys.

Šiuo metu senamiesčio teritorijoje priskaičiuojama daugiau kaip dešimt dideliu privataus kapitalo investiciju, kuriu bendra suma viršija $70 \mathrm{mln}$. Lt. Vilniaus miesto statiniu statybos inspekcijos duomenimis, senamiestyje $1997 \mathrm{~m}$. užbaigti ir priimti eksploatuoti 75, o 1998 m. - 91 objektas (per metus jų skaičius padidejjo 16). I šị skaičių neịeina smulkūs darbai (palèpių tvarkymas, laiptinių remontas ir pan.). Didžiausią dali priimtu eksploatuoti objektu sudare verslo paskirties objektai, kuriụ lyginamoji dalis $1997 \mathrm{~m}$. siekè 50,7\%, o $1998 \mathrm{~m}$. - 59,3\%. Iš jų didžiausią dali sudarè parduotuvès $(28 \%)$, maitinimo istaigos ir biurai $(18,7 \%)$. Antrają vietą užèmè gyvenamosios paskirties objektai.

Investuotojams svarbu pasirinkti tinkamiausius rekonstruojamy pastatụ pritaikymo variantus, tai yra išnagrinèti nekilnojamojo turto paklausą ir, remiantis suformuluotais pastato pritaikymo variantais, išnagrinèti sąnaudas, kurių reikia šiems variantams realizuoti.

Šiuo metu Lietuvoje investiciniai senamiesčiu pastatu atnaujinimo projektai dažniausiai vertinami pagal vieną kriteriju - projekto pelną.
Toks vertinimo būdas neleidžia plačiau pažvelgti i visą sudètingą investavimo procesą. Ekonominèje literatüroje bendras tiek kiekvienos investicinio projekto stadijos, tiek ir viso investicinio projekto vertinimas skiriasi. Dalis autorių $[1,2]$, investiciju ekonomini rezultatą teisingai laikydami dominuojančiu, kitus - socialinius, ekologinius ir techninius efektyvumo rodiklius vertina atskirai vienus nuo kitu ir ju neitraukia $i$ apibendrinančią investiciju vertinimo rodiklių sistemą. Šie autoriai mano, kad tarp atskiru efektyvumo rodiklių yra tik nereikšmingi ryšiai, nesusiję su ekonominiais rezultatais, kurie yra tik vienos priežasties pasekmè, pavyzdžiui, mokslinè-techninè veikla yra mokslinio-techninio lygio priežasčių pasekmè. Iš tiesų, jeigu investiciniam projektui sukurtume efektyvumo rodiklių sistemą, sudarytą iš visų rodiklių, rodančių, kuo investicinis projektas skiriasi nuo kitų, tai socialiniai, techniniai ir kiti rodikliai, kaip sudedamoji efektyvumo rodikliu sistemos dalis, gali pasireikšti kaip atskiri efektyvumo rodikliai, kuriu reikia techninei ekonominei investicijų analizei [3, 4].

V. Cerniakas [4] siūlo taikyti ivairius techninius, ekonominius ir socialinius efektyvumo rodiklius. Kadangi efektyvumo rodikliu yra labai daug, jis siūlo taikyti pafaktorinę analizę lyginant ivairius variantus su etaloniniu variantu. Bendruoju atveju taikoma ivertinimo formule:

$$
K=\frac{\sum_{0}^{n}\left(N \cdot F_{i}\right)}{\sum_{0}^{m}\left(N \cdot F_{c t}\right)},
$$

$K$ - ekonominio ir socialinio efekto vertinimo kriterijus; $\sum F_{i}, \sum F_{p t}$ - vertinamo projekto etalono nagrinejjamų veiksnių $(n, m)$ suma; $N$ - skaičiuojamasis mato vienetas.

Gyvenamuju pastaty rekonstrukcijos variantini projektavimą nagrinèja A. Šreiberis [5]. Remdamasis 
E. K. Zavadsko darbu [6], variantinio projektavimo problemas jis siūlo spręsti selektonovacijos metodais. Rekonstrukcijos variantų analizei A. Šreiberis taiko techninius-ekonominius ir socialinius rodiklius - rekonstrukcijos sąnaudas, eksploatacijos kaina, pastato komfortiškumą. A. Šreiberis ypač akcentuoja pastato komfortiškumo reikšmę.

E. K. Zavadskas, A. Kaklauskas ir E. Bejderis [7] variantinio statybos projektavimo uždavinius sprendžia selektonovacijos metodais. Statybos projektu efektyvumą jie siūlo vertinti dviem etapais. Pirmuoju etapu nustatomi geriausi variantai. Kitu etapu geriausi variantai yra kombinuojami i alternatyvius projektus. Tuomet taikant selektonovacijos metodus išrenkami geriausi variantai. E. Bejderis statybos projektų analizę siūlo atlikti vertinant sąmatinę kainą, eksploatavimo charakteristikas ir kokybines charakteristikas [8].

Senamiesčiu pastatu renovacijos daugiavariantinio investavimo uždaviniai nebuvo sprendžiami selektonovacijos metodais. Autoriai senamiesčių pastatụ renovacijos uždaviniams spręsti sudaré naują efektyvumo rodiklių sistemą ir pasiūlè metodus, kuriais galima nustatyti senamiesčiu pastatu renovacijos investicinių projektu racionalumą.

\section{Efektyvumo rodiklių reikšmingumų nustatymas porinio palyginimo metodu}

Taikant sprendimy̨ prièmimo sistemą, suformavus rodiklius, svarbu nustatyti jų reikšmingumus. Tai gali būti padaryta ekspertinio porinio palyginimo metodu, kuri pateikè T. Saaty [9].

Porinio palyginimo metodas yra geras tuo, kad ekspertai gali palyginti rodiklius tarpusavyje po du, kas yra svarbu lyginant daug rodikliu. Grupinis vertinimas gali būti laikomas pakankamai patikimu tik tada, kai apklausiamy specialistų nuomonès yra suderinamos. Todèl statistiškai apdorojant iš ekspertụ gautą informacija, reikètu ivertinti ju nuomonių suderinamumą ir nustatyti informacijos nevienareikšmiškumo priežastis. Porinio palyginimo metodas nenumato ekspertu nuomoniu suderinamumo patikrinimo, todèl siūlome taikyti ekspertinio metodo [10] ekspertu nuomoniu suderinamumo tikrinimo būdą, kurị pateikè L. Evlanovas [11].

Pagal porinio palyginimo metodą naudojantis ekspertu (specialistų) suteikiama informacija nustatomi efektyvumo rodikliụ reikšmingumai. Šių rodik- liụ reikšmingumu reikšmèms gauti reikia informacijos, kuri gaunama poromis lyginant rodiklius ir nustatant ju „tarpusavio svarbumo intensyvumą". Nustatant prioritetiškumą, verta naudotis rodiklių reikšmingumu skale, kurią pasiūlè T. Saaty [9] (1 lent.).

1 lentelè. T. Saaty rodiklių reikšmingumu skalè [9]

Table 1. Scale of importances given by T. Saaty [9]

\begin{tabular}{|c|l|}
\hline $\begin{array}{c}\text { Svarbumo } \\
\text { lygis }\end{array}$ & \multicolumn{1}{|c|}{ Apibréžimas } \\
\hline 1 & Rodikliai vienodai svarbūs \\
\hline 3 & Vienas rodiklis truputị svarbesnis už kitą \\
\hline 5 & Vienas rodiklis daug svarbesnis už kitą \\
\hline 7 & Vienas rodiklis daug daugiau svarbesnis už kitą \\
\hline 9 & Vienas rodiklis nepalyginamai svarbesnis už kitą \\
\hline
\end{tabular}

Iš 1 paveiksle pateikto užpildytos anketos pavyzdžio matyti, kad pirmasis ir antrasis rodikliai yra vienodai svarbūs, trečiasis rodiklis yra nepalyginamai svarbesnis už pirmajii, o antrasis rodiklis yra daug svarbesnis už trečiajị.

\begin{tabular}{|c|c|c|c|}
\hline & 1 rodiklis & 2 rodiklis & 3 rodiklis \\
\hline 1 rodiklis & & 1 & $1 / 9$ \\
\hline 2 rodiklis & 1 & & 5 \\
\hline 3 rodiklis & 9 & $1 / 5$ & \\
\hline
\end{tabular}

1 pav. Anketos pildymo pavyzdys

Fig 1. Example for filling in a questionaire

Turint užpildytas ekspertų nuomoniu anketas, sudaroma lentelè, i kurią irašomos ekspertu pateiktų rodiklių vidutinès reikšmès. Tuomet atliekami tolesni matematiniai skaičiavimai.

Tarkime, turime $m$ variantu, aprašomų $n$ rodikliais. Prioritetiškumo rodiklis žymimas $b_{i j} ; i, j=\overline{1, n}$. Šis rodiklis reiškia eksperto ivertintụ $i$-ojo ir $j$-ojo rodikliụ reikšmingumų santykị. Pažymèjus eksperto $j$-ojo rodiklio ìvertinimą simboliu $\omega_{j}$,

$$
b_{i j}=\frac{\omega_{i}}{\omega_{j}}
$$

Tarkime, kad poromis buwo palyginti visi rodikliai ir nustatytos skaitinès jụ prioritetiškumo reikšmès. Ver- 
tinimo rezultatai pateikiami matricoje $B$ :

$$
B=\left[\begin{array}{cccc}
b_{11} & b_{12} & \ldots & b_{1 n} \\
b_{21} & b_{22} & \ldots & b_{2 n} \\
\ldots & \ldots & \ldots & \ldots \\
b_{n 1} & b_{n 2} & \ldots & b_{n n}
\end{array}\right]=\left[\begin{array}{cccc}
\frac{\omega_{1}}{\omega_{1}} & \frac{\omega_{1}}{\omega_{2}} & \ldots & \frac{\omega_{1}}{\omega_{n}} \\
\frac{\omega_{2}}{\omega_{1}} & \frac{\omega_{2}}{\omega_{2}} & \ldots & \frac{\omega_{2}}{\omega_{n}} \\
\ldots & \ldots & \ldots & \ldots \\
\frac{\omega_{n}}{\omega_{1}} & \frac{\omega_{n}}{\omega_{2}} & \ldots & \frac{\omega_{n}}{\omega_{n}}
\end{array}\right] .
$$

Matyti, kad

$$
b_{i j}=\frac{\omega_{i}}{\omega_{j}}, b_{j i}=\frac{\omega_{j}}{\omega_{i}} \text { arba } \quad b_{i j}=\frac{1}{b_{j i}} .
$$

Todèl pakanka palyginti ne visas rodiklių poras, o tik nepasikartojančias. Nepasikartojančių porų skaičius yra $\frac{n(n-1)}{2}$.

Skaitinès rodiklių reikšmingumy reikšmès $\omega_{j}(j=\overline{l, n})$ nustatomos sprendžiant optimizavimo uždavini:

$$
\min \left\{\sum_{i=1}^{n} \sum_{j=1}^{n}\left(b_{i j} \omega_{j}-\omega_{i}\right)\right\} .
$$

kai nežinomieji $\omega_{j}(j=\overline{1, n})$ tenkina apribojimus:

$$
\sum_{i=1}^{n} \omega_{i}=1, \omega_{i}>0 ;(i=\overline{1, n}) .
$$

Kadangi apribojimas $\omega_{i}>0$ yra neesminis, jis gali būti praleistas.

Uždavinys sprendžiamas tradiciniu būdu: nustatoma Lagranžo funkcija, jos laisvieji nariai prilyginami nuliui. Optimalus sprendimas gaunamas išsprendus tiesinių lygčių sistemą:

$$
C \cdot Q=m,
$$

kur $Q=\left(q_{1}, q_{2}, \ldots, q_{n}, \lambda_{1}\right)^{T} ; q_{i}$ - rodikliụ reikšmingumo reikšmès; $\lambda_{1}$ - Lagranžo daugiklis; $m=\underbrace{(0,0, \ldots, 0,1)^{T}}_{n k \text { karm }}$. $C=\left[l_{i}\right], i, j=1, \ldots, n, n+1$ - matrica, turinti $n+1$ stulpelių ir $n+1$ eilučių, kurios elementai nustatomi pagal formules:

$$
\begin{gathered}
l_{i i}=(n-1)+\sum_{j=1}^{n} b_{j i}^{2}, i, j=1, \ldots . n, \\
l_{i j}=-\left(b_{i j}+b_{j i}\right), i, j=\overline{1, n} ; i \neq j, \\
l_{k, n+1}=l_{n+1 . k}=1, k=\overline{1, n}, \\
l_{n+1 . n+1}=0 .
\end{gathered}
$$

Grupinis vertinimas gali būti laikomas pakankamai patikimu tik tada, kai apklausiamų specialistų nuomonès yra suderinamos. Todèl, statistiškai apdorojant ekspertų pateiktą informaciją, reikètu ivertinti jų nuomonių suderinamumą ir nustatyti informacijos nevienareikšmiškumo priežastis [11].

Pagal kiekvieną anketą nustatomi kriterijų rangai. Gaunami $t_{j k}$ reikšmiu rinkiniai (2 lent.).

2 lentelè. Ekspertų apklausos rezultatai

2 table. Results of the questionaire

\begin{tabular}{|c|c|c|c|c|}
\hline \multirow{2}{*}{ Ekspertas } & \multicolumn{5}{|c|}{ Efektyvumo rodiklis } \\
\hline$E_{1}$ & $t_{11}$ & $t_{31}$ & $\ldots$ & $t_{\mathrm{n} 1}$ \\
\hline$E_{2}$ & $t_{12}$ & $t_{22}$ & $\ldots$ & $t_{\mathrm{n} z}$ \\
\hline$\ldots$ & $\ldots$ & $\ldots$ & $\ldots$ & $\ldots$ \\
\hline$E_{\mathrm{k}}$ & $t_{1 \mathrm{r}}$ & $t_{2 \mathrm{r}}$ & $\ldots$ & $t_{\mathrm{nr}}$ \\
\hline $\begin{array}{l}\text { Rangu } \\
\text { suma }\end{array}$ & $\sum_{i=1}^{k} t_{1 k}$ & $\sum_{i=1}^{k} t_{2 k}$ & $\ldots$ & $\sum_{i=1}^{k} t_{n k}$ \\
\hline $\begin{array}{l}\text { Vidutinis } \\
\text { rangas }\end{array}$ & $\overline{t_{1}}$ & $\overline{t_{2}}$ & $\ldots$ & $\overline{t_{n}}$ \\
\hline
\end{tabular}

Vidutinis rangas nustatomas pagal formulę:

$$
\bar{t}_{1}=\left(\sum_{k=1}^{r} t_{j k}\right): r,
$$

$t_{j k}-k$ eksperto $j$-ojo rodiklio ivertinimas; $r$ - ekspertu skaičius.

Ekspertizès patikimumas gali būti išreikštas konkordancijos koeficientu, nusakančiu atskiru nuomoniu panašumo laipsni, kuris išreiškiamas:

$$
\bar{W}=\frac{12 S}{r^{2}\left(n^{3}-n\right)-r \sum_{k=1}^{r} T_{k}},
$$

$S$ - kiekvieno efektyvumo rodiklio nukrypimo kvadraty suma:

$$
\begin{gathered}
S=\sum_{j=1}^{n}\left[\sum_{k=1}^{r} t_{j k}-\frac{1}{n} \sum_{j=1}^{n} \sum_{k=1}^{r} t_{j k}\right]^{2}, \\
T_{k}=\sum_{l=1}^{H_{l}}\left(h_{l}^{3}-h_{l}\right),
\end{gathered}
$$

$T_{k}$ - tarpusavyje susijusiu rangu $k$ rangavimo rodiklis; $H_{l}$ - lygių rangu grupiụ skaičius $k ; h_{l}-k$-ojo eksperto nustatytụ lygiụ rangụ skaičius $l$-ojoje grupejje; $t_{j k}-$ $k$ eksperto $j$-ajam rodikliui priskiriamas rangas; $r-$ ekspertų skaičius; $n$ - efektyvumo rodiklių skaičius. 
Jeigu susijusių rangu nėra, konkordancijos koeficientas randamas pagal formulę:

$$
\bar{W}=\frac{12 S}{r^{2}\left(n^{3}-n\right)} \text {. }
$$

Konkordancijos koeficientas lygus 1, jeigu visi ekspertu rangavimai vienodi, ir lygus 0 , jeigu visos jos skirtingos, t. y. visiškai nesutampa.

Koeficientas, randamas pagal formules (13) ir (16), turi atsitiktini dydi. Pagal [11] konkordancijos koeficiento reikšmei nustatyti reikia žinoti $r$ ekspertu skaičiaus $n$ lyginamu objektų skirtingų reikšmiu pasiskirstymo dažnị. Konkordancijos koeficiento reikšmé nustatoma pagal formulę:

$$
\chi^{2}=\frac{12 S}{m(n+1)-\frac{1}{n-1} \sum_{k=1}^{r} T_{i}}
$$

Jeigu pagal (17) formulę gauta $\chi^{2}$ reikšmè didesnè negu norminè $\chi_{\text {lent }}^{2}$ reikšmè, priklausanti nuo laisvumo laipsnio ir reikšmingumo lygio, laikoma, kad ekspertu nuomonès suderintos. Priešingu atveju, kai $\chi^{2}<\chi_{\text {lem }}^{2}$, laikoma, kad ekspertu nuomonès nesuderintos ir labai skiriasi.

\section{Variantų racionalumo nustatymas artumo idea- liajam taškui metodu}

Yoonas ir Hwangas [12, 13] sukūré variantu prioritetiškumo nustatymo metodiką, pagrịstą koncepcija, kad optimali alternatyva turi mažiausią atstumą nuo idealaus sprendimo ir didžiausią atstumą nuo idealiai blogiausio sprendimo. Šis metodas vadinamas variantu racionalumo nustatymu artumo idealiajam taškui metodu (TOPSIS - Technique for Order Preference $b y$ Similarity to Ideal Solution).

Tarkime, kad kiekvieno rodiklio reikšmès yra pastoviai didejančios arba pastoviai mažejjančios. Tada galima rasti idealų sprendimą, kuris yra sudarytas iš geriausiu rodikliụ reikšmių, ir neigiamai idealu sprendima, kuris yra sudarytas iš blogiausių rodikliụ reikšmių.

Sukuriama sprendimų matrica $P$ :

$$
\begin{aligned}
& \begin{array}{llll}
X_{1} & X_{2} & \ldots & X_{n}
\end{array}
\end{aligned}
$$

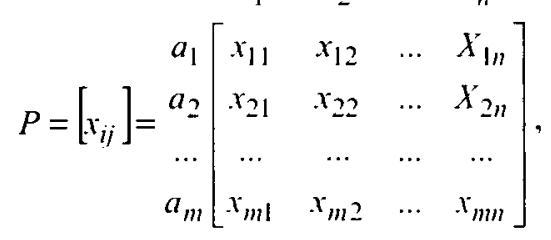

kur $a_{l} \ldots a_{m}$ - lyginamieji variantai $(i=1, m) ; X_{l} \ldots X_{n}-$ efektyvumo rodikliai $(j=1, n) ; x_{1} \ldots x_{m n}$ - efektyvumo rodiklių reikšmès.

$\breve{S i}$ matrica normalizuojama pagal formulę:

$$
\overline{x_{i j}}=\frac{x_{i j}}{\sqrt{\sum_{i=1}^{m} x_{i j}^{2}}} ; i=\overline{1, m} ; j=\overline{1, n}
$$

ir gaunama normuotoji matrica $\bar{P}$, kurios visos efektyvumo reikšmès - bedimensiai dydžiai:

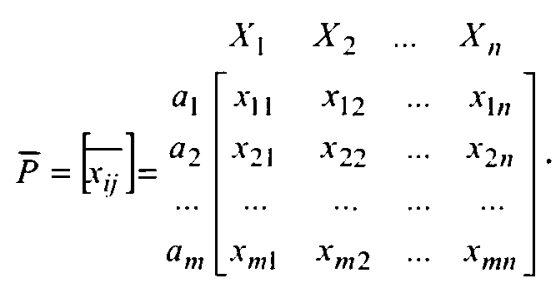

Sudaroma svertinè normuotoji matrica $\overline{P^{*}}$. Jei yra žinomi efektyvumo rodikliụ reikšmingumai, tai matrica $\overline{P^{*}}$ apskaičiuojama pagal formulę:

$$
\overline{P^{*}}=[\bar{P}][q],
$$

o jei reikšmingumai nežinomi, tada $\overline{P^{*}}=P$.

Idealiai geriausias variantas nustatomas pagal formulę:

$$
\begin{gathered}
a^{+}=\left\{\left[\left(\max _{i} f_{i j} \mid j \in J\right),\left(\min _{i} f_{i j} \mid j \in J^{\prime}\right)\right] / i=\right. \\
=\overline{1, m}\}=\left\{f_{1}^{+}, f_{2}^{+}, \ldots, f_{n}^{+}\right\},
\end{gathered}
$$

kur $J$ - rodiklių, kuriems didesnès reikšmès yra geresnès, indeksų aibė; $J^{\prime}$ - rodiklių, kuriems mažesnès reikšmès yra geresnès, indeksų aibè.

Neigiamai idealus variantas nustatomas pagal formulę:

$$
\begin{gathered}
a^{-}=\left\{\left[\left(\min _{i} f_{i j} \mid j \in J\right),\left(\max _{i} f_{i j} \mid j \in J^{\prime}\right)\right] / i=\right. \\
=\overline{1, m}\}=\left\{f_{1}^{-}, f_{2}^{-}, \ldots, f_{n}^{-}\right\} .
\end{gathered}
$$

Atstumas tarp lyginamojo $i$-ojo ir idealiai geriausio $L_{i}^{+}$varianto nustatomas pagal formulę:

$$
L_{i}^{+}=\sqrt{\sum_{i=1}^{n}\left(f_{i j}-f_{i j}^{+}\right)^{2}} ; i=\overline{1, m},
$$

o tarp $i$-ojo ir neigiamai idealaus $L_{i}^{-}$- pagal formulę:

$$
L_{i}^{-}=\sqrt{\sum_{i=1}^{n}\left(f_{i j}-f_{i j}^{-}\right)^{2}}: i=\overline{1, m} .
$$

Nustatomas kiekvieno $i$-ojo varianto santykinis atstumas iki idealaus: 


$$
K_{B I T}^{+}=\frac{L_{i}^{-}}{L_{i}^{+}+L_{i}^{-}}, i=\overline{1, m}
$$

kai $K_{B I T}[0,1]$.

Kuo $K_{B I T}$ reikšmé artimesnè vienetui, tuo $i$-asis variantas artimesnis $\mathrm{a}^{-}, \mathrm{t} . \mathrm{y}$. racionalus variantas bus tas, kurio $K_{B I T}$ reikšmė yra didžiausia.

Remiantis $K_{B I T}$ reikšmejmis, sudaroma variantų prioritetụ eilutè, pavyzdžiui:

$$
\left\{a_{i}\right\}=a_{1} \succ a_{3} \succ a_{2}
$$

kur ženklas $\succ$ reiškia, ,geriau už“.

\section{Nagrinèta situacija}

Tyrimo objektu pasirinktas pastatas Vilniaus senamiestyje. Ivertinus nekilnojamojo turto senamiestyje paklausą ir pasiūlą, buvo iškeltas uždavinys išanalizuoti 5 skirtingus investicinius variantus: buty su daline apdaila irengimas, butu su visa apdaila irengimas, viešbučio be apdailos ir su apdaila irengimas, esamos būklès pastato realizavimas.

Nuo $1998 \mathrm{~m}$. i ši objektą jau buvo investuota 1800 tūkst. Lt (iš ju 1600 tūkst. Lt pastatui pirkti ir 200 tūkst. Lt parengiamiesiems rekonstrukcijos darbams). Be to, gautas leidimas ir planuojama atstatyti nugriautą pastato korpusą šioje posesijoje.

Rekonstruojamas objektas - buvęs gyvenamasis namas. Patalpu bendrasis plotas prieš rekonstrukciją - $460 \mathrm{~m}^{2}$, numatomas patalpu bendrasis plotas po rekonstrukcijos - $1235,11 \mathrm{~m}^{2}$.

Pastatas yra dviejų aukštų su nenaudojama palèpe. Labai vertingi XV a. skliautuoti gotikiniai rūsiai. Pamatai juostiniai, mūryti iš akmenų ir plytu, dalis jụ suirę. Reikia stiprinti apie $60 \%$ pamatu. Sienos mūrinès, molio plytų. Keliụ kapitalinių sienų būklè avarinè, yra žymių plyšių.

Pastato perdangos - sijinès medinès, avarinès būklès. Stogo konstrukcijos medinès, danga - keraminès čerpès. Stogas avarinès būklès: medinès laikančiosios konstrukcijos pažeistos puvinio ir grybo, stogo danga susidèvẻjusi. Vidaus laiptai - mediniai, avarinès būklès. Sąramos plytụ mūro. Langai ir durys mediniai, smarkiai susidèvèję. Pertvaros medinés, grindys - daugiausia lentų, susidèveję. Vidaus elektros, vandentiekio ir buities nuotėkų tinklai avarinès būklès. Centralizuoto šildymo sistemą reikia keisti. Yra patenkinamos būklès dujotiekio tinklai. Lauko vandentiekio ir nuotèkų tinklai pasenę, juos reikia keisti.
Dujotiekio lauko tinklai patenkinamos būklès. Elektros tinklu ivadai ir tranzitiniai miesto elektros tinklai pasenę.

Yra gautas leidimas atstatyti buvusị korpusą šiaurrytiniame posesijos kampe ir taip uždaryti kiemą.

Praeivių srautas pro statybos vietą nèra labai didelis, nes pagrindinis judejjimas vyksta kitomis gatvèmis. Tačiau nagrinejjamas pastatas yra netoli judriu gatvių.

Parduotuviu irengimo varianto buvo iš anksto atsisakyta, nes nedidelis praeiviu srautas yra rimta kliūtis sèkmingai prekybai šioje vietoje.

Didelis pastato trūkumas yra tai, kad nèra vietos automobiliams pastatyti, nes artimiausiu metu tuščią gretimą posesiją numatoma užstatyti. Mažiausią itaką šis trūkumas turètų viešbučio irengimo variantui.

Pirmuoju ir antruoju variantais rūsyje ir pirmajame aukšte numatomos komercinès paskirties patalpos, antrajame aukšte ir mansardoje - butai.

\section{Rinka}

Rinkos duomenys (pvz., gyvenamojo ploto poreikis, informacija apie viešbučių rinką) buvo analizuoti naudojantis Vilniaus bendruoju planu [14].

Atnaujintu patalpu senamiestyje kaina yra 4000 - $16000 \mathrm{Lt} / \mathrm{m}^{2}$ (vidutiniškai $6400 \mathrm{Lt} / \mathrm{m}^{2}$ ) [15]. Komercinès paskirties patalpu rūsyje kaina yra panaši $\mathfrak{i}$ patalpu pirmajame aukšte kainą.

Mansardos ir visu likusių patalpu vertè skaičiuojama atskirai, nes patalpụ mansardoje vertè yra 10$15 \%$ mažesnè. Patalpu plotas mansardoje yra $325,56 \mathrm{~m}^{2}$ (neskaitant bendrojo naudojimo patalpų). Butu ir rūsio plotas yra 743,48 $\mathrm{m}^{2}$ (neskaitant bendrojo naudojimo patalpu). Esamos būklès patalpu rinkos vertè yra $743,48 \cdot 2000+325,56 \cdot 1850=2089246$ Lt. Patalpu rinkos vertė atlikus pagrindinių konstrukcijų remontą, keitima, tvirtinima, lauko ir vidiniu komunikacijų keitima, fasado remonta, langy keitima yra $743,48 \cdot 5 \quad 200+325,56 \cdot 4 \quad 420=5305071 \quad$ Lt.

Patalpų rinkos vertè atlikus visą apdailą yra $743,48 \cdot 7000+325,56 \cdot 6 \quad 000=7157720 \mathrm{Lt}$.

Patalpu rinkos vertė irengus viešbuti be apdailos iskaitant bendrojo naudojimo plotus $1241 \cdot 5010=$ $=6215056 \mathrm{Lt}$.

Patalpu rinkos vertè visiškai įrengus viešbuti yra $1241 \cdot 9200=11417200 \mathrm{Lt}$.

Rinkodaros strategijos tikslas - užtikrinti projekto igyvendinimo pelninguma. Tam numatoma siekti, kad 
planuojamas parduoti pastatas igytu paklausą, būtų patrauklus pirkẻjams, jo rinkos kaina būtu didesnè už idètas lèšas. Pastato paklausą tikimasi padidinti specialiojoje spaudoje išsamiai informuojant apie pastatą ir galimybes ji isigyti. Optimizuojant pastato panaudojimo variantus atliktas variantinis investicijų poreikio skaičiavimas. Nagrinèti šie investiciju ir pardavimo variantai:

1) esamos būklès pastato realizavimas;

2) pastato realizavimas atlikus pagrindinių konstrukciju remontą, keitimą, tvirtinimą, lauko ir vidiniu komunikaciju keitimą, fasado remontą, langu keitimą;

3) pastato realizavimas irengus butus (su visa apdaila);

4) pastato realizavimas irengus viešbuti (be apdailos ir irangos);

5) pastato realizavimas irengus viešbutị (su visa apdaila).

Pastatas parduodamas dalimis. Jo renovacijos rinkodaros modelio schema pateikta 2 paveiksle. Numatomi keli pastato panaudojimo variantai. Pavyzdžiui, jame galima irengti butus, kavinę arba viešbutị. Kiekvienam iš šių variantu sudaroma sąmata. Žinant išlaidas, kurių reikès visiems variantams, atliekami rinkodaros skaičiavimai: žiūrima, kuris iš variantų yra pigesnis, koki galima gauti pelną, pastatą pardavus arba išnuomojus, kokia turi būti pardavimo kaina, kad grižtụ idètos léšos ir būtụ gautas numatytas pelnas. Lyginant ¡vertinama galima pardavimo kaina. Jeigu planuojama imti kreditus, numatomi kredito èmimo ir investavimo etapai, palūkanų augimas.

Pagal pagrindinius rodiklius parenkamas geriausias variantas.

Galutinis veiklos etapas: pastatas rekonstruojamas ir parduodamas. Patalpos parduodamos rekonstrukcijos metu.

Projektas nèra rizikingas, kaip ir visos investicijos i nekilnojamąii turtą. Rizika, susijusi su atstatomuoju objektu, statybos montavimo darbais, apdraudžiama.

\section{Investicijų analizė}

Projektui igyvendinti numatyta imti kreditus dalimis vieno mènesio intervalu, metinè palūkanų norma $10 \%$.

Visiems skirtingiems projektams buvo sudaryti darbu vykdymo tvarkaraščiai. 2 ir 3 paveiksluose pateikiami kalendoriniai darbụ vykdymo tvarkaraščiai, kai pastatas irengiamas su visa apdaila ir be apdailos.

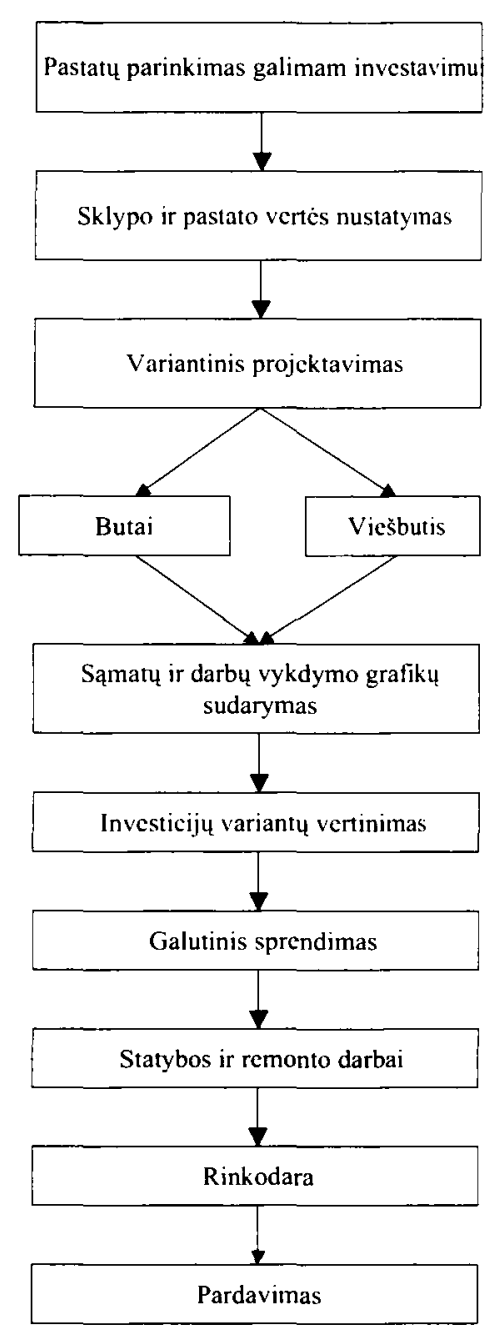

2 pav. Pastato rekonstrukcijos rinkodaros modelis

Fig 2. Model of building reconstruction marketing

Visiems pastato rekonstrukcijos variantams sudaromos sąmatos. Pastatui ísigyti ir paruošiamiesiems darbams jau buvo išleista 1800 tūkst. Lt. Pastato konstrukciju remontas ir keitimas, vidaus santechnikos ir elektros darbai, fasado ir kiemo tvarkymas kainuos 1340 tūkst. Lt (be apdailos). Irengiant viešbuti šie darbai kainuos 1608 tūkst. Lt. Lauko tinklụ remontas kainuos apie 441 tūkst. Lt.

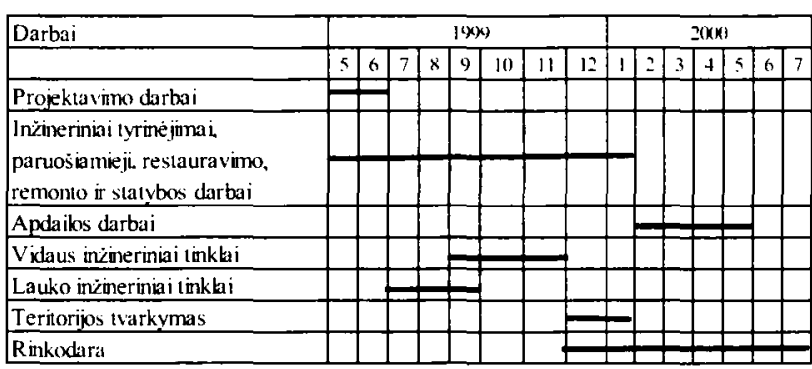

3 pav. Kalendorinis darbų vykdymo tvarkaraštis, kai pastatas irengiamas su visa apdaila

Fig 3. Schedule of reconstruction work with interior trim 


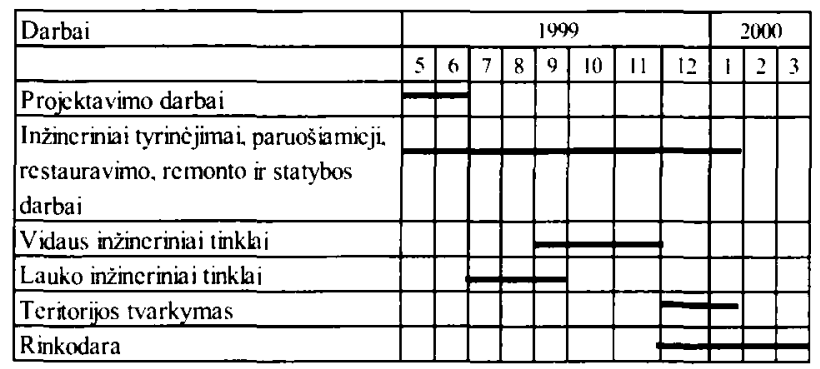

4 pav. Kalendorinis darbų vykdymo tvarkaraštis, kai pastatas irengiamas be apdailos

Fig 4. Schedule of reconstruction work without interior trim

Remiantis sąmatiniais skaičiavimais ir kitais duomenimis išanalizuotas projektų pelningumas (3 lent.). Pirmiausia reikia apibréžti siekiamus tikslus. Nagrinèjamų efektyvumo rodiklių sąrašas sudarytas, atsižvelgiant i sprendžiamų uždavinių pobūdị loginès analizès būdu [16], stengiantis, kad rodikliai tarpusavyje būtu kuo labiau nepriklausomi. Nustatant svarbiausius rodiklius peržvelgtos 5 veiksniu grupès: valdymo tikslai (pelnas, kokybè, terminai, augimo potencialas), išorinès sąlygos (rinkos dinamika, konkurencija, istatyminè bazè), informacijos palyginimas (informacijos šaltiniai, patikimumas), organizaciniai veiksniai (struktūra, ivaizdis, politika, žmonių elgesys), operaciniai veiksniai (ištekliụ poreikis, patalpos, kaina) [17].

Remiantis šiais principais investicijų i pastatą variantai lyginti pagal 14 rodiklių, tai:

- pelningumas,

- pastato ilgaamžiškumas,

- eksploatavimo išlaidos,

- verslo perspektyvos,

- pastato komfortiškumas,

- pardavimo kaina,

- šilumos izoliacija,

- galimi nuostoliai del konstrukcijų suirimo,

- pastato pirkimo ir rekonstrukcijos kaina,

- pastato vieta,

- nuomos kaina,

- laikotarpis nuo pastato rekonstrukcijos pradžios iki jo realizacijos,

- vietos automobiliui pastatyti buvimas,

- pastato išvaizda.

Pastato ilgaamžiškumas pateiktas metais, eksploatavimo išlaidos - dešimtimis tūkstančių litụ. Verslo perspektyvos vertintos balais. Pastato komfortiškumas vertintas balais (mažiausia yra neịrengto pastato komfortiškumo rodiklio reikšmè). Pastato pardavimo kaina pateikta milijonais litu, remiantis rinkos kainomis. Pelningumas sprendimu matricoje (4 lent.) pateiktas milijonais litų, remiantis 3 lentele. Iš renovuoto pastato rinkos kainos atemus savikainą, gautas projekto pelnas. Savikainai nustatyti visiems variantams sudarytos sąmatos [18]. Pastato sienų šilumos izoliacija pateikiama $\mathrm{m}^{2} \mathrm{~K} / \mathrm{W}$ [19]. Galimi nuostoliai dèl konstrukcijų suirimo išreiškiami žmonių skaičiumi kvadratiniame pastato metre. Pastato pirkimo ir rekonstrukcijos kaina pateikiama milijonais litų. Ši suma gaunama prie objekto issigijimo kainos pridejus sąmatinę darbu kainą.

Pastato vieta, išvaizda ir vieta mašinai pastatyti vertinama balais. Nuomos kaina išreikšta $\mathrm{Lt} / \mathrm{m}^{2}$ [15]. Laikotarpis nuo pastato renovacijos pradžios iki jo realizacijos pateikiamas mènesiais, sudarius darbų atlikimo tvarkaraščius.

Rodikliu, pagal kuriuos buvo vertinti investiciju variantai, reikšmingumai buvo nustatyti apklausus 18 ekspertu: mokslininkų, verslininku ir statybininkų.

Atlikus ekspertu užpildytų anketu analizę, sudaryta viena bendra anketa, kurioje surašytos vidutinès ekspertų pateiktu vertinimu reikšmès. Apdorojus šią anketą porinio palyginimo metodu pagal (2)-(11) formules, gautas rodiklių reikšmingumo vektorius $\{q\}=\{0,200,0,0646,0,0429,0,0629,0,0699,0,0643$, $0,0428,0,0376,0,0647,0,1226,0,0655,0,0702$, $0,1439,0,1480\}$.

Kitu etapu buvo tikrinamas ekspertų nuomoniu suderinamumas.

Apdorojus kiekvieno eksperto anketą porinio palyginimo metodu, gauta tiek rodikliu reikšmingumų vektorių, kiek ekspertų pildè anketas. Turint kiekvieno eksperto rodikliu reikšmingumo vektorius nustatytas konkordancijos koeficientas. Skaičiuojant pagal (12)-(17) formules šio koeficiento reikšmingumas $\chi^{2}=64,44$ yra didesnis už jo norminę reikšmę $\chi_{l c m}^{2}=26,22$. Vadinasi, ekspertu nuomonès yra suderintos ir jomis galima pasitiketti.

Kitu etapu sudaryta sprendimu matrica, t. y. surašytos visų variantų efektyvumo rodikliụ reikšmès (4 lent.).

Variantų racionalumas buvo nustatytas artumo idealiajam taškui metodu.

4 lenteleje pateiktą sprendimụ matricą išsprendus artumo idealiajam taškui metodu pagal (18)-(25) formules, gautos variantų racionalumo reikšmès. Variantụ santykiniai atstumai iki idealaus $K_{B I T}$ pateikti 5 lentelèje. 


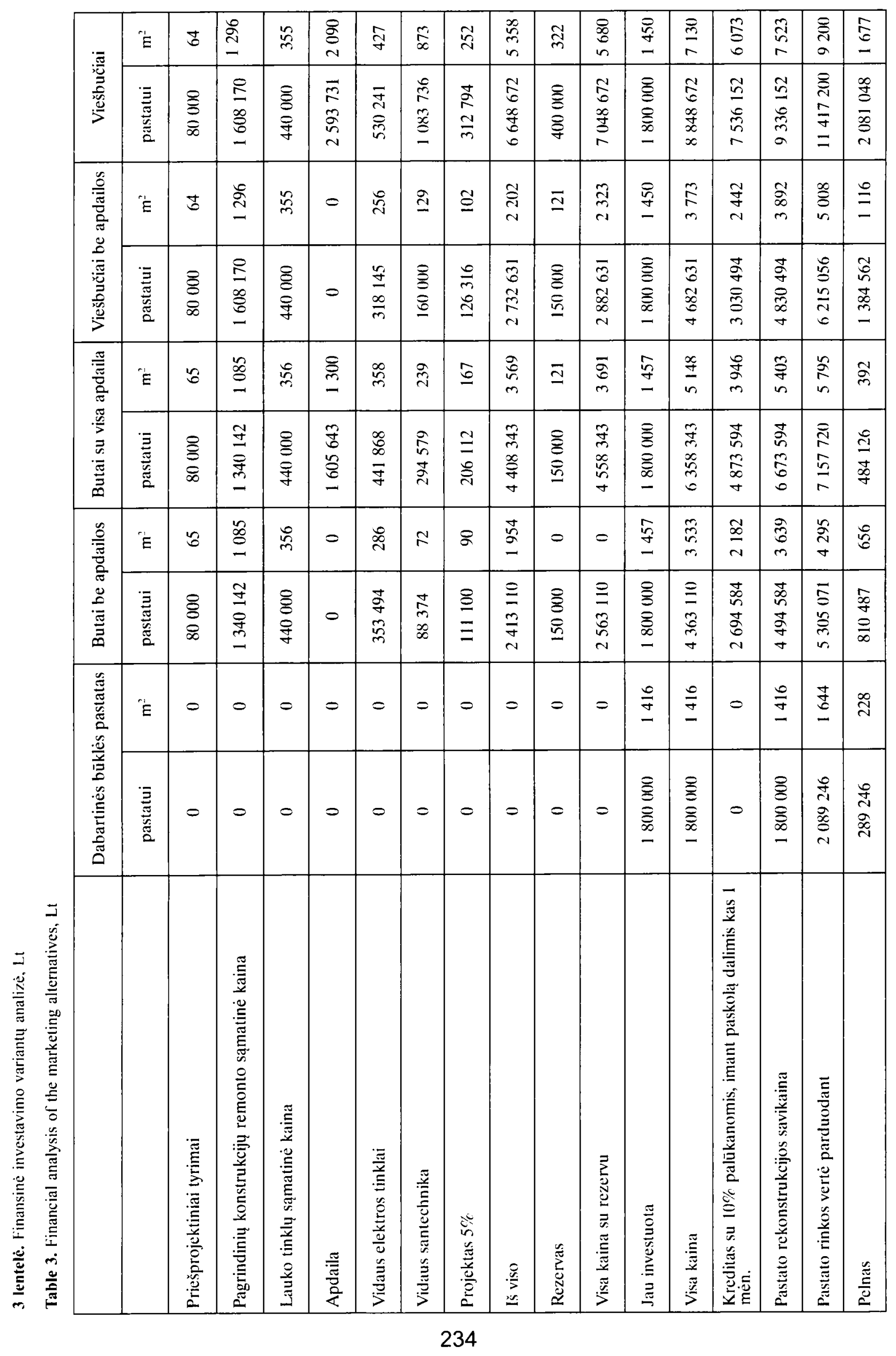


4 lentelè. Sprendimų matrica

Table 4. Decision matrix

\begin{tabular}{|c|c|c|c|c|c|c|c|c|}
\hline \multicolumn{2}{|l|}{ Rodiklis } & \multirow[t]{2}{*}{$\begin{array}{l}\text { Reikšmin- } \\
\text { gumas q }\end{array}$} & \multirow[t]{2}{*}{$\begin{array}{c}\text { Minimizuo- } \\
\text { jamas ar } \\
\text { maksimizuojamas }\end{array}$} & \multirow{2}{*}{\begin{tabular}{|c|}
$\begin{array}{c}\text { Esamos } \\
\text { būklès } \\
\text { pastatas }\end{array}$ \\
$\mathrm{a}_{1}$ \\
\end{tabular}} & \multirow{2}{*}{$\begin{array}{c}\begin{array}{c}\text { Butai su } \\
\text { daline } \\
\text { apdaila }\end{array} \\
\mathrm{a}_{2}\end{array}$} & \multirow{2}{*}{$\begin{array}{c}\begin{array}{c}\text { Butai } \\
\text { su visa } \\
\text { apdaila }\end{array} \\
a_{3} \\
\end{array}$} & \multirow{2}{*}{$\begin{array}{c}\text { Viešbutis } \\
\text { su daline } \\
\text { apdaila }\end{array}$} & \multirow{2}{*}{$\begin{array}{r}\begin{array}{r}\text { Viešbutissu } \\
\text { visa apdaila }\end{array} \\
a_{5} \\
\end{array}$} \\
\hline & & & & & & & & \\
\hline Pelnas & $x_{1}$ & 0,200 & $\max$ & 0,29 & 0,81 & 0,48 & 1,38 & 2,08 \\
\hline Pastato ilgaamžiškumas & $\mathrm{x}_{2}$ & 0,148 & $\max$ & 0,1 & 80 & 80 & 80 & 80 \\
\hline Eksploatavimo išlaidos & $\mathrm{x}_{3}$ & 0,144 & $\min$ & 1 & 1 & 1 & 1 & 3 \\
\hline Verslo perspektyvos & $x_{4}$ & 0,123 & $\max$ & 1 & 1 & 1 & 1 & 1 \\
\hline Pastato komfortiškumas & $\mathrm{x}_{5}$ & 0,070 & $\max$ & 0,6 & 1 & 1 & 1,2 & 1,2 \\
\hline Pardavimo kaina & $x_{6}$ & 0,070 & $\max$ & 2,09 & 5,31 & 7,16 & 6,22 & 11,36 \\
\hline Šilumos izoliacija & $\mathrm{x}_{7}$ & 0,066 & $\max$ & 3 & 3 & 3 & 3 & 3 \\
\hline $\begin{array}{l}\text { Galimi nuostoliai dèl } \\
\text { konstrukcijų suirimo }\end{array}$ & $\mathrm{x}_{\mathrm{s}}$ & 0,065 & $\min$ & 4 & 1 & 1 & 1 & 1 \\
\hline $\begin{array}{l}\text { Pastato pirkimo ir } \\
\text { renovacijos kaina }\end{array}$ & $x_{y}$ & 0,065 & $\min$ & 1,8 & 4,49 & 6,67 & 4,83 & 9,34 \\
\hline Pastato vieta & $\mathbf{x}_{1 ! \prime}$ & 0,065 & $\max$ & 1 & 1 & 1 & 1 & 1 \\
\hline Nuomos kaina & $x_{11}$ & 0,063 & $\max$ & 40 & 40 & 40 & 40 & 40 \\
\hline $\begin{array}{l}\text { Laikotarpis iki pastato } \\
\text { realizacijos }\end{array}$ & $x_{12}$ & 0,043 & $\min$ & 2 & 11 & 15 & 11 & 15 \\
\hline $\begin{array}{l}\text { Vieta automobiliams } \\
\text { pastatyti }\end{array}$ & $\mathrm{x}_{13}$ & 0,043 & $\max$ & 0,5 & 0,5 & 0,5 & 1 & 1 \\
\hline Pastato išvaizda & $x_{14}$ & 0,038 & $\max$ & 5 & 10 & 10 & 10 & 10 \\
\hline
\end{tabular}

Variantai pagal efektyvumą išsirikiavo tokia tvarka: $a_{4} \succ a_{5} \succ a_{2} \succ a_{3} \succ a_{1}$, kur $\succ$ ženklas reiškia ,geriau už“.

5 lentelè. Variantu santykiniai atstumai iki idealaus $K_{B I r}$

Table 5. Relative distances of the variants to the ideal point $K_{B I r}$

\begin{tabular}{|c|c|c|}
\hline Investavimo variantas & $K_{B I T}$ & Prioritetiškumas \\
\hline $\mathrm{a}_{1}$ & 0,353 & 5 \\
\hline $\mathrm{a}_{2}$ & 0,557 & 3 \\
\hline $\mathrm{a}_{3}$ & 0,492 & 4 \\
\hline $\mathrm{a}_{4}$ & 0,709 & 1 \\
\hline $\mathrm{a}_{5}$ & 0,647 & 2 \\
\hline
\end{tabular}

\section{Išvados}

1. Pasiūlyta daugiakriterinio vertinimo metodika senamiesčių pastatụ renovacijos variantams analizuoti. Suformuluoti vertinimo kriterijai. Buvo apklausti aš- tuoniolika pastaty renovacijos srityje dirbančiu profesionalų - nekilnojamojo turto specialistų, investuotoju, statybininku. Taikant porini ekspertini metodą, nustatyti vertinimo kriterijų reikšmingumai.

2. Metodika išbandyta analizuojant pastato Vilniaus senamiestyje renovacijos variantus. Išspręstas realus uždavinys pradedant variantų sudarymu ir baigiant variantu prioritetiškumo nustatymu. Gauti rezultatai rodo, kad efektyviausia pastatą panaudoti viešbučiui irengti. Pastato renovacija vykdoma atsižvelgus šias išvadas.

\section{Literatūra}

1. K. C. Myers. Buy It, Fix It, Sell It: Profit! Dearborn Financial Publishing, 1997. 350 p.

2. D. Isaac. Property investment. Macmillan Press Ltd, 1998, $336 \mathrm{p}$.

3. В. А. Смирнов. Организационно-экономические основы инвестирования проектов недвижимости. Санкт-Петербург: Издательство СПбГУЭФ, 1999. $166 \mathrm{c}$. 
4. В. 3. Черняк. Управление инвестиционным проектом в строительстве. Москва: Русская деловая литература, 1998. $800 \mathrm{c}$.

5. К. А. Шрейбер. Вариантное проектирование при реконструкции жилых зданий. Москва: Стройиздат, 1990. 287 c.

6. Э. К. Завадскас. Многошелевая селектоновация технологических решений строительного производства (Теоретические основы). Вильн.-инж. стронт. институт. Вильнюс: ВИСИ, 1988. 108 с.

7. E. Zavadskas, A. Kaklauskas, E. Bejder. Multiple criteria analysis of projects. Aalborg: Aalborg universitetscenter, 1992. $93 \mathrm{p}$.

8. E. Bejder. Statybos pramonès kompaniju kokybinès sistemos: kūrimas, vystymas, kreipiant ypatingą demesi $\mathrm{i}$ suinteresuotu grupių interesu derinimą: Daktaro disertacijos tezès. Vilnius: Technika, 1994. 28 p.

9. T. L. Saaty. A scaling method for priorities in hierarchical structures. Journal of Mathematical Psychology. Vol 15. No 3, 1977, p. 234-281.

10. Э. К. Завадскас. Комплексная оценка и выбор ресурсосо̃ерегающих решений в строительстве. Вильнюс: Мокслас, 1987. 212 с.

11. Л. Г. Евланов. Теория и практика принятия решений. Москва: Экономика, 1984. 176 с.

12. K. Yoon. Systems selection by Multiple Attribute Decision Making. Ph. D. Dissertation, Kansas State University, Manhattan, Kansas, 1980.

13. K. Yoon, Ch. L. Hwang. TOPSIS (Technique for Order Preference by Similarity to Ideal Solution-A multipple Attribute Decission Making). 1980.

14. Vilniaus miesto teritorijos bendrasis planas. Vilniaus miesto tarybos $1998 \mathrm{~m}$. gruodžio mèn. $18 \mathrm{~d}$. sprendimo Nr. 292 priedas. Vilnius: Briedis, 1999. 79 p.

15. Lithuanian market report. Ober Haus Real Estate Co. Spring 1999. Tallinn, $8 \mathrm{p}$.

16. Э. К. Завадскас. Системотехническая оценка технологических решений строительного производства. Ленинград: Стройиздат, 1991. 256 с.

17. M. W. Davis. Applied decission support. New Jersey: Prentice-Hall, 1988. 135 p.

18. LR aplinkos ministro $2000 \mathrm{~m}$. sausio $18 \mathrm{~d}$. isakymas .,Dèl skaičiuojamuju kainu normatyvu patvirtinimo ir Statybos ir urbanistikos ministerijos $1998 \mathrm{~m}$. sausio $19 \mathrm{~d}$. [sakymo Nr. 7 dalinio pakeitimo". I p.

19. Pastatų atitvarų šiluminè technika. STR 2.05.01:1999. Statybos techninis reglamentas / Lietuvos Respublikos aplinkos ministerija. Vilnius, 1999. $167 \mathrm{p}$.

Iteikta 20000824

\section{APPLICATION OF MULTICRITERIA DECISION METHODS IN RESTORATION OF BUILDINGS IN THE OLD TOWN}

\section{Ustinovičius, S. Jakučionis}

Summary

The largest part of old towns in Lithuania are to be regenerated. Sociological evaluation made in 1998 in Vilnius showed that the main problem of the Old Town are falling buildings.

Nowadays investment into real estate is evaluated according to a single criterion. That's why it is so complicated to review the whole investment process.

The object under investigation is the buildings in Vilnius Old Town. Condition of building constructions was evaluated. The location of building and possibilities of building usage are being€ evaluated also.

Vilnius real estate market data was collected from Vilnius general plan. Values of building at various stages of reconstruction are calculated. There are 5 different alternatives of marketing.

The scheme of building marketing is presented in Fig 2. There are schedules of the reconstruction work made (Figs 3 and 4). An estimation of different alternatives of building reconstruction is calculated (Table 3 ).

Alternatives of building regeneration were evaluated in accordance with 14 criteria: profit of the project, life-time of building. price of the maintenance, perspectives of business, comfortability of building, price of building sale, insulation, possible losses because of accidents, cost of the building acquiring and reconstruction, location of building, price of the rent, term from the building acquiring till realisation, place for car parking and appearance. Decision matrix is presented in Table 4

Rationality of alternatives was calculated using TOPSIS method. Ranking of alternatives is presented in Table 5.

We suppose that multi-criteria evaluation of the investment options creates new possibilities for investors and helps to choose the best variant of the building usage.

Leonas USTINOVIČIUS. Doctor (technical sciences), Associate Professor. Dept of Civil Engineering. Vilnius Gediminas Technical University (VGTU). Sauletekio al. 11. LT-2040 Vilnius, Lithuania. E-mail: promenadostatyba@operamail.com

First degree in Construction Engineering at Vilnius Civil Engineering Institute (now VGTU), 1982. Doctor (1989), Associate Professor (1993). Author of more than 70 articles and manuals. Research interests: construction technology, old town regeneration. IT in construction, multicriteria analysis.

Sigitas JAKUČIONIS. PhD student (civil engineering), Dept of Civil Engineering. Vilnius Gediminas Technical University (VGTU). Saulètekio al. 11, LT-2040 Vilnius, Lithuania. E-mail: $s(\omega r l . l t$

MSc in Civil Engineering at VGTU, (1996). Research visits: Leipzig University of Applied Sciences (Germany, 1997, 1999), Lund University (Sweden, 1998). Research interests: old town regeneration, IT in construction, multicriteria analysis. 